\title{
Value stock and growth stock on Indonesia stock exchange after global crisis
}

\author{
MUHAMMAD FADHIL RABBANI', HARJUM MUHARAM1 \\ ${ }^{1}$ Department of Management, Faculty of Economics and Business, Universitas Diponegoro
}

\begin{abstract}
This study was conducted to determine whether there are differences between the stock return of value stocks and growth stock in Indonesia before and after the world financial crisis that occurred in 2008. To investigate the difference, the stocks formed into a portfolio that is based on the 2002 calculated in 2002 and 2009 when the world financial crisis has ended. The formation of the portfolio based on stocks that have gone public before 2000 and have the complete data during the study period. For the determination of the categories of stocks used Price-to-Earnings ratio, price-to-book ratio and price-to-cash flow ratio. Shares of stock that has a very high ratio will be eliminate to avoid bias that may occur if the stocks are still included. Similarly, the stocks of which are negative because they do not meet the criteria as a value stock. Then ANOVA test conducted to determine differences in returns and Sharpe ratio on the portfolio which was formed in 2002 and in 2009. Results from this studies are not found differences in returns and Sharpe ratio on both the portfolio. This indicates that the formation of the portfolio by value stocks and growth stock can not be used as a guide to get a high return.
\end{abstract}

\section{INTRODUCTION}

Many people are still in doubt and confused to do an investment in capital market. However, it is easy to invest in capital market, and there are many ways to pick a stock. One of them is to make a portfolio. It means that an investor can easily spread (make a difersivication) it's investment in any opportunity (Suad Husnan: 43). In this case investor make a diversivication to reduce their accounted risk (Suad Husnan: 45). So does Markowitz (1954) who said that a portfolio must be diversified to minimize the risk. Every investor have their own preference and different risk level that can be taken. The higher the expected profit, the bigger the risk that must be accounted.

There are many ways to pick a stock, one of them is by classification. Often times stocks are classified in value and growth categories by investors (Jenn Yaw Yen, Qian Sun dan Yuxing Yan 2004). Value stock and growth stock was first introduced by Graham and Dodd (1934). The simple definition from value stocks and growth stocks according to Fama and French, (1993) are: value stocks are those stocks that traded with lower prices compared to it's fundamentals (e.g. earnings, book value, cash flow, dividends) whereby growth stocks are those stocks that traded with higher prices compared it's fundamentals. While Jenn Yaw Yen, Qian Sun and Yuxing Yan (2004) stated that value (growth) stocks described as something that has to do with the relatively low (high) market price in relation to some estimates of intrinsic value, like price to book value $(P / B)$, price to earnings $(\mathrm{P} / \mathrm{E})$, and price to cashflow $(\mathrm{P} / \mathrm{C})$.

Many studies conclusively record that value stocks outperform growth stocks (value premium) in US and Japan. Fama and French (1998;2007) and Black and Millian $(2004 ; 2006)$ studied about value stocks and growth stocks with return, risk and the whole performance. The results are value stocks outperform growth stocks. Basu (1977) also shows that stocks in US with lower price to earnings $(P / E)$ tend to have higher rate return than stocks with higher (P/E) (e.g. growth stocks). Chan, Hamao and Lakonishok (1991) also found the same thing in Japan stock market. This research is also proven by Fama and French (1992, 1993, 1996), Lakonishok, Shleifer and Vishny (1994) and Chan and Lakonishok (2004) US and Europe 
stock market, Australia and EAFE. However, the invention may also be a problem anomaly for rational expectations, because it is based on conventional wisdom, options for growth depends on the economic conditions in the future and to be more risky than the assets in place (Zhang, 2005).

Based on history, a stock with higher book to market ratio get a higher return rate than stocks with lower book to market ratio. The difference in return rate of value and growth stocks, that commonly known as value premium, is about $6 \%$ every year, which known to give a threat as a serious challenge towards standard asset pricing model like capital asset pricing model (CAPM) (Hengjie Ai and Dana Kiku: 2013).

A global crisis that occured in 2008 weakened all the capital market in the world. But Indonesia can overcome it very well so that IHSG price not declining too many. Strangely, IHSG price rise and reach the second highest in ASEAN after previously in third position. So it is possible to affect the value of investor's stock portfolio.

This research aims to find if there is a difference between portfolio return and sharpe portfolio of value stocks and growth stocks in Indonesia stock exchange and if value stocks have a higher return from growth stocks in Indonesia stock exchange.

\section{THEORETICAL FRAMEWORK AND HYPOTHESES DEVELOPMENT}

\section{Value stocks and growth stocks}

Graham and Dodd (1994) were one of the first shcolars to acknowledge that value stocks and growth stocks are each other's enemy. They also gave definition about those two stocks. While according to Jenn Yaw Yen, Qian Sun and Yuxing Yan (2004) value (growth) stocks described as something that has to do with the relatively its low (high) market price in relation to some estimates of intrinsic value, like price to book value $(P / B)$, price to earnings $(P / E)$, dan price to cashflow $(\mathrm{P} / \mathrm{C})$.

\section{Value stocks}

Value stocks are stocks with it's price to earnings $(P / E)$, price to book $(P / B)$, and or price to cashflow $(\mathrm{P} / \mathrm{C})$ are lower compared to market average (Graham and Dodd 1934; Fama and French, 1998; Chan and Lakonishok, 2004; Athanassakos, 2009).
Graham and Dodd (1934) stated that this exaltation happen due to poor performance in the past in wich the expectation arises that this performance will continue in the future. However, poor perfomance does not have to refer in particular towards default. It could also be a signal that the company reached its maturity in which the company's growth becomes stable and does not give any indication anymore of excessive growth.

\section{Growth stocks}

Graham and Dodd (1934) defined growth stocks as a stock that traded in a relative high price compared to it's fundamental. Growth stocks can be characterized as a stocks with expected return and growth substantially higher than the market average and a probability to rise further (Bourguignon and De Jong, 2003). Investors believe that this rise are known as growth (or glamour) stocks.

\section{Classifying stocks as value or growth}

There are many ways to classify stocks as a value stocks or growth stocks. But, there are 3 ratios that mostly used by scholars, which are price-to-earnings (P/E), price-to-book $(\mathrm{P} / \mathrm{B})$, and price-to-cashflow (P/C) or equivalent from these ratios, such as marketto-book, book-to-market, earning-to-price, and cash flow-to-price. These ratios are commonly used because that ratios create a stable results (Fama and French, 1998).

\section{Value premium}

Value premium or value-growth spread exist when value stocks outperform growth stocks in certain condition (Capaul et al, 1993). This value premium is very important since the results lead to whether investors are more confidence to buy value or growth stocks. The higher the value premium, the more likely it is that investors to choose value stocks due to the higher returns compared to growth stocks (Bird and Casavvechia, 2007). When this figure is between zero, it will indicate an ignorance in buying value or growth stocks. When this figure is below zero, it will indicate the existence of discount value, which is growth stocks give a higher return from value stocks. When value premium is significantly and substantially higher than market return, then a potential bubble is shaped (Brown et al, 2008). 


\section{Value premium in emerging market}

Fama and French (1998) analyzed possible value premiums in 16 emerging markets. From the observation, found evidence of a value premium that was remarkably high (14,13 percent) compared to developed international markets. Huang Yang (2008) also observed a positive value premiums in the China stok market. Brown et al (2008) who researched emerging market in Asia record an existence of value premium in Hong Kong (0,72 percent), Korea $(0,42$ percent) and Singapore (0,42 percent) but a value discount in Taiwan (1,26 percent).

At first, IHSG is kown as a low index in ASEAN, however since 2004 IHSG grow exceeding Thailand and Malaysia, even higher than Singapore after the financial crisis in 2008 till now. An interesting phenomenom where IHSG grow dramatically after the financial crisis. It can be concluded that Indonesia stock market also have many value and growth stocks and very interesting to investors. So does a research about value premium phenomenom in Indonesia stock exchange. That is why two hypotheses can be made:

H1: There are differences in portfolio return between value stocks and growth stocks in Indonesia Stock Exchange during 2002-2015.

H2: Value stocks has a bigger return than growth stocks in Indonesia stock Exchange during 2002-2015.

\section{Portfolio theory}

Markowitz (1954) said that a portfolio must be diversified to reduce the risk. Ross (1976) in APT (Arbitrage Pricing Theory) said that if an investment have the same characteristic cannot be sold with a different price, if those investments sold with different price then there will be a chance to get return or profit without risk.

\section{Stocks and portfolio return}

Stock return is a result gained from invesment or rate of profit gained by investor from an investment that have been done (Hartono 2000: 107). Many investor make an investment to get a maximum return. Stock return is divided into two, which are return that already happen called actual return. While expected return is a return that expected. This return is used to determine risk in the future. This two return used by investors as a tool to forecast stock return that they owned (Halim, 2003).

$$
R i=\frac{P 1-P_{o}+D 1}{P_{0}}
$$

$\mathrm{Ri}$ is the return for stock $\mathrm{i}, \mathrm{P}_{1}$ is price for time $1, P_{0}$ is price for time $0, D_{1}$ is dividend for time 1.

To calculate portfolio, return, this research use this formula:

$$
\mathrm{R}_{\mathrm{py}}=\sum_{\mathrm{i}=1}^{n} w_{\mathrm{i}} \mathrm{R}_{\mathrm{i}}
$$

$R_{p y}$ is the monthly portfolio return in month $y$, $\mathrm{W}_{\mathrm{i}}$ is the individual weight of a stock in a portfolio, $R_{i}$ is the return of stock $i$.

\section{Sharpe ratio}

Capaul et al (1993) stated that sharpe ratio is a measure of the reward obtained per unit risk. For an investment, reward is measured by the average excess return (return minus riskless rate) and risk by the standard deviation of excess returns.

$$
S i=\frac{R i-R F R}{\sigma i}
$$

$\mathrm{RI}$ is the average rate of return for portfolio $i$ during a specified time period, RFR is the average rate of return on risk-free assets during the same time period, this research use $\mathrm{BI}$ rate as risk-free rate and $\sigma_{\mathrm{i}}$ as the standard deviation of the rate of return for portfolio $i$ during the time period.

The higher the sharpe ratio, the better and higher the performance and return invesment. In every case, the value index provided the best results (Capau et al, 1993). Because of that, this research will evaluate whether value stocks in Indonesia have a higher sharpe ratio than growth stocks on Indonesia Stock Exchange during the time period of research. The next two hypotheses are:

H3: There are differences in portfolio sharpe ratio value stocks and growth stocks on Indonesia Stock Exchange during 2002-2015.

H4 : Value stocks have a higher sharpe ratio than growth stocks on Indonesia Stock Exchange during 2002-2015. 
Tabel 1.

Post Hoc Test for portfolio 2002

\begin{tabular}{lcccccr} 
Based on & (I) Category & (J) Category & $\begin{array}{c}\text { Mean } \\
\text { Difference (I-J) }\end{array}$ & Std. Error & $\begin{array}{c}\text { Sig. } \\
\text { Tukey } \\
\text { HSD }\end{array}$ & $\begin{array}{c}\text { Sig. } \\
\text { Bonferroni }\end{array}$ \\
\hline P/E 2002 & value & Growth & $-42,37833$ & 51,25083 & 0,6933 & 1,000 \\
\hline P/B 2002 & value & Growth & $-18,97167$ & 63,70368 & 0,952 & 1,000 \\
\hline P/C 2002 & value & Growth & 9,50167 & 64,48845 & 0,988 & 1,000 \\
\hline & & & Sharpe ratio & & 1,000 \\
\hline P/E 2002 & value & Growth & $-103,93167$ & 129,16255 & 0,706 & 1,000 \\
\hline P/B 2002 & value & Growth & 1,28833 & 86,39743 & 1,000 & 0,933 \\
\hline P/C 2002 & value & Growth & 87,76333 & 87,33983 & 0,585 & \\
\hline
\end{tabular}

\section{METHODS}

\section{Variables}

The price-earnings or $\mathrm{P} / \mathrm{E}$ is the ratio of the current stock price to last year's earnings per share. P/E ratio tells us how much stock purchasers must pay per dollar of earnings that the firm generates (Bodie et al. 2011). The lower (higher) rates of $\mathrm{P} / \mathrm{E}$ give the perception that the expectation on future earnings will also be lower (higher) (Bodie et al, 2009). consequently, stocks with a low $\mathrm{P} / \mathrm{E}$ ratio are categorized as value stocks and stocks with a high $\mathrm{P} / \mathrm{E}$ ratio are categorized as growth stocks.

$$
\mathrm{P} / \mathrm{E}=\frac{P y}{E P S f}
$$

Where $\mathrm{P}_{y}$ is the daily average closing price of a company's stock in a fiscal year $y, E P S_{f}$ is Earning per share at fical year end $(\mathrm{FYE})_{f}$.

Price-to-book ratio or $P / B$ is a fianncial ratio used to compare a copany's current market price to its book value. It is also sometimes known as a Book-to-Market ratio (Wikipedia). Fama and French (1998) have used this ratio to separate value and growth stocks. A higher (lower) market price of a stock gives an indication that investors have assigned additional (no) value to a company (Bodie et al, 2009). Stocks with a low P/B ratio are categorized as value stocks and stocks with a high $\mathrm{P} / \mathrm{B}$ ratio are categorized as growth stocks.

$\mathrm{P} / \mathrm{B}$ ratio $=\overline{\text { TAf }-(\text { IAf }+ \text { TLf }) / \text { Total Shares }}$ Where $\mathrm{P}_{y}$ is the daily average closing price of a company's stock in fiscal year $y, \mathrm{TA}_{f}$ is total assets at FYE $f, \mathrm{IA}_{f}$ is intangible assets at FYE $f$, adn $\mathrm{TL}_{f}$ is total liabilities at FYE $f$.
Price-to-cash flow ratio is used by investors to evaluate the invesment attractiveness from a standpoint of a company's stock. P/C ratio compares the stock's market price to the amount of cash flow the company generates on a per-share basis. Chan and Lakonishok (2004) argue that $\mathrm{P} / \mathrm{C}$ has become extremelypopular to classify value and growth stocks since it views the company's performance from a different point of cash in- and outflows as compared to earnings. ). Stocks with a low $\mathrm{P} / \mathrm{C}$ ratio are categorized as value stocks and stocks with a high $\mathrm{P} / \mathrm{C}$ ratio are categorized as growth stocks.

$$
\mathrm{P} / \mathrm{C}=\frac{P y}{\text { NOCFf } / T S}
$$

Where $\mathrm{P}_{y}$ is the daily average closing price of a company's stock in fiscal year $y, \mathrm{NOCF}_{f}$ is net operating cash flowat FYE, and TS is total shares.

\section{Sampling}

Population in this research is all companies that listed in Indonesia Stock Exchange during 2001-2015. Samples taken in this research are stocks that already listed in Indonesia stock exchange since 2000 and can provide data that needed completely during 2002-2015. For companies that are new-listed after year 2000 or delisted between those period will be excluded. So does a financial institutions will be excluded because it can trigger biases when making a decision about value premium because of it's leverage and financial multiples are not equally the same as for non financial institutions (Fama and French (1993). 
Table 2.

Post Hoc Test for portfolio 2009

\begin{tabular}{lcccccr} 
Based on & (I) Category & (J) Category & $\begin{array}{c}\text { Mean } \\
\text { Difference }(\mathbf{I}-J)\end{array}$ & Std. Error & $\begin{array}{c}\text { Sig. } \\
\text { Tukey } \\
\text { HSD }\end{array}$ & $\begin{array}{c}\text { Sig. } \\
\text { Bonferroni }\end{array}$ \\
\hline P/E 2009 & value & Growth & $-16,15333$ & 23,51092 & 0,774 & 1,000 \\
\hline P/B 2009 & value & Growth & 32,81000 & 18,78367 & 0,211 & 0,303 \\
\hline P/C 2009 & value & Growth & 11,85167 & 23,87833 & 0,874 & 1,000 \\
\hline & & & Sharpe ratio & & & 1,000 \\
\hline P/E 2009 & value & Growth & $-30,74333$ & 50,07911 & 0,815 & 1,000 \\
\hline P/B 2009 & value & Growth & 45,92667 & 70,66577 & 0,795 & 1,000 \\
\hline P/C 2009 & value & Growth & $-12,16333$ & 39,23126 & 0,949 & \\
\hline
\end{tabular}

\section{RESULTS AND ANALYSIS}

This research used ANOVA and conducted four tests, which are: test of homogeneity variance, test of between subjects, post hoc test and homogenous subset. It was used to test relationship between one independent variabel with one or more other independent variabels (Ghozali, 2013).

Variable used in this research are Price to Earning $(\mathrm{P} / \mathrm{E})$ ratio, Price to Book $(\mathrm{P} / \mathrm{B})$ ratio, and Price to cash flow $(\mathrm{P} / \mathrm{C})$ ratio that used to separate value and growth stock and return portfolio. $P / E$ ratio is a ratio from current stock price with Earning Per Share. P/E ratio give information about how much stock buyer must pay for every dollar revenue that produced by the company. High (low) P/E give a perception about revenue in the future is also high (low) (Bodie et. al, 2011). P/B ratio is a financial ratio that commonly used to compare current stock market price of a company with it's book value. High (low) P/B ratio can be explained that the company is overvalued (undervalued). $\mathrm{P} / \mathrm{C}$ ratio is a ratio which used to compare a company's market value to its own cash flow. This ratio is also used to measure the market prospects of the company's assets in the future from financial point of view (Bragg, 2007). value (growth) stock categorization is based from $P / E, P / B$, and $P / C$ ratio, where a stock with the lowest (highest) ratio will be categorized as value (growth) stock.

In the first hypothesis stated that there are differences in portfolio return of value stocks and growth stocks on Indonesia Stock Exchange during 2002-2015. However, result from test above shows that the difference between classifications return of value and growth is not significant in $0,05(\mathrm{p}<0,05)$, it means that $\mathrm{HO}$ is accepted and $\mathrm{H} 1$ is rejected. Then statistically there is no difference in portfolio return between all classifications in Indonesia, eventhought in some of the classifications found that there are some categories with positive results, during research period time for portfolio construction based on $\mathrm{P} / \mathrm{E}, \mathrm{P} / \mathrm{B}$ and $\mathrm{P} / \mathrm{C}$ in year 2002 and 2009. Therefore, first hypothesis is rejected.

Second hypothesis stated that value stocks have a bigger return than growth stocks on Indonesia stock exchange during 2002-2015. However, result from mean difference shows that not every return rate disparity between value stocks with growth stocks have a positive score. So does with the result from research above stated not significant in $0,05(p<0,05)$. Hence, it can be concluded that $\mathrm{H} 0$ is accepted and $\mathrm{H} 2$ is rejected.

Third hypothesis stated that there are differences in sharpe ratio portfolio of value stocks and growth stocks on Indonesia Stock Exchange during 2002-2015.result from However, test above shows that the difference between sharpe ratio classification of value and growth is not significant in 0,05 $(p>0,05)$, it means that $\mathrm{HO}$ is accepted and $\mathrm{H} 3$ is rejected. Afterwards, statistically there is no difference in sharpe ratio between all classifications in Indonesia, eventhought in some of the classifications found that there are some categories with positive results, during research period time for portfolio construction based on $\mathrm{P} / \mathrm{E}, \mathrm{P} / \mathrm{B}$ and $\mathrm{P} / \mathrm{C}$ from 2002 to 2009. Therefore, third hypothesis is rejected. 
Fourth hypothesis stated that value stocks have a bigger sharpe ratio than growth stocks on Indonesia Stock Exchange during 2002-2015. However, results from mean difference shows that not every disparity sharpe ratio rate between value stocks with growth stocks have a positive score. As well as the result from research above stated not significant in $0,05(p<0,05)$. Hence, it can be concluded that $\mathrm{HO}$ is accepted and $\mathrm{H} 4$ is rejected.

\section{CONCLUSION}

The majority result from Post Hoc test are more than 0,05 which means that there is no difference in return portfolio in all categories. This means that $\mathrm{H} 1$ which stated that there is a difference between portfolio return in Indonesia from year 2002 to 2015 rejected. So does with the majority results from Post Hoc test are more than 0,05 which means that there is no difference in sharpe ratio portfolio in all caegories. This means that $\mathrm{H} 2$ which stated that there is a difference between sharpe ratio in Indonesia from year 2003 to 2015 rejected.

Although the result from hypothesis test mathematically support the hypothesis, however, statistically based on ANOVA test, there is no meaningful difference in return and sharpe ratio in this research. Based on statistic data, it can be concluded that return from each stock in portfolio are not affected by classifications (growth, medium dan value) and those classifications cannot explain return from each stock in portfolio. And every growth, medium and value classification statistically cannot become a foundation to make a portfolio. So does a risk that measured with sharpe ratio for value stocks does not have a difference with growth stocks in Indonesia.

Our research has some limitations. A small sample caused by limited data. Independent variabel consist only return and sharpe ratio. Then the risk measurement using only Sharpe Ratio.

Based on the research above, it is found no difference between value and growth stock in Indonesia during research period time. Hence, classification of stock into value and growth stock cannot become a guidance for investor to create a portfolio for achieving a higher return in the future. For future research, it is expected tha researcher increase variabel, sampel size, other measurements and countries than Indonesia

\section{REFERENCES}

Athanassakos, G. (2009). Value versus growth stock returns and the value premium: the Canadian experience 1985-2005. Canadian journal of Administrative Sciences, Vol. 26, $p$. 109-121.

Bird, R. \& Casavecchia, L. (2007). Sentiment and financial health indicators for value and growth stocks: The European experience. The European Journal of Finance, Vol. 13 (8), $p$. 769-793.

Cronqvist, H., Siegel, S. \& Yu, F. (2015). Value versus growth investing: Why do different investors have different styles?. Journal of Financial Economics, Vol. 117, p. 333-349.

Fama, E.F. \& French, K.R. (2007). The anatomy of value and growth stock returns, Financial Analysis Journal, Vol. 63 (6), p. 44-54.

Ghozali, Imam. (2013). Aplikasi Analisis Multivariate dengan Program SPSS 20. Semarang: BP UNDIP.

Graham, B. \& Dodd, D.L. (1934). Security Analysis NY, United States. McGraw Hill New York.

Hoekjan, R.M. (2011). The Performance of Value VS Growth Stocks during The Financial Crisis. Turkey: Master Thesis University of Twente.

Huang, Y. \& Yang, J. (2008). Value premium in the Chinese stock market: free lunch or paid lunch?, working paper, p. 1-31.

Husnan S. (2003). Dasar-Dasar Teori Portofolio dan Analisis Sekuritas. Yogyakarta: AMP YKPN.

In, F., Kim, S. \& Gencay, R. Investment horizon effect on asset allocation between value and growth strategies. Journal Economy Modelling, Vol 28, p. 1489-1497.

Olin, Tomi. (2011). Value Investing in the Finnish Stock Market. Master Thesis Aalto University School of Economics.

Santoso, Singgih. (2015). Menguasai SPSS 22 From Basic to Expert Skills. Jakarta: PT Elex Media Komputindo.

The Brandes Institutes. (2012). Value vs. Glamour: A Global Phenomenon. Sandiego: Worldscope: The brandes Institutes.

Yen, J.Y., Sun, Q., \& Yan, Y. (2004). Value versus growth stocks in Singapore. Journal of Multi Finance Management, Vol 14, p. 19-34.

Yesica, E., (2014). Value vs growth stocks returns on the Indonesia stock exchange study to companies listed on Indonesia Stock Exchange 2003-2013 period. Semarang: Universitas Diponegoro. 